\title{
Jubileusz 80-lecia urodzin Karola Daniela Kadłubca
}

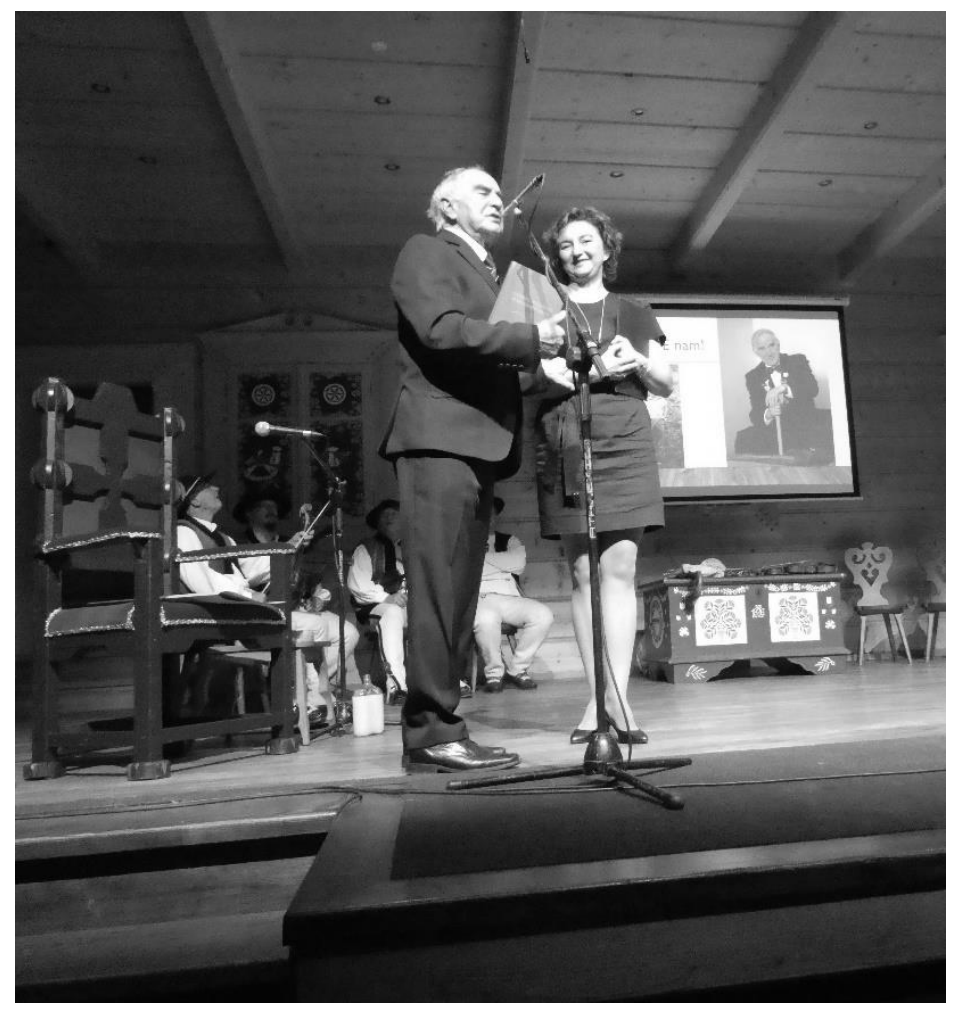

Profesor Karol Daniel Kadłubiec, znakomity badacz i popularyzator kultury, folkloru i języka Śląska Cieszyńskiego, autor wielu publikacji książkowych i kilkuset artykułów urodził się 22 lipca 1937 r. w rodzinie polskiego nauczyciela i społecznika, zamieszkującego przysiółek zwany Fojstwie we wsi Karpętna (czes. Karpentná, obecnie dzielnica Trzyńca), w powiecie Frýdek-Místek w kraju morawsko-śląskim. Miejsce urodzenia - Zaolzie i domowe wychowanie, kładące nacisk na ewangelicki system wartości, zwłaszcza etos pracy i wiedzy oraz szacunek dla odmienności kulturowej, wywarły niemały wpływ na późniejsze dokonania naukowe i społeczno-oświatowe Jubilata.

Jako sześciolatek uczył się w - jedynej wówczas - niemieckiej szkole ludowej, po 1945 r. zaś uczęszczał do polskiej szkoły podstawowej w Bystrzycy (czes. Bystřice) i polskiego liceum w Czeskim Cieszynie, by po jego ukończeniu 
w 1955 roku rozpocząć studia slawistyczne na Uniwersytecie Karola w Pradze, chlubnie zakończone w 1960 r. dyplomem magisterskim (za rozprawę poświęconą bajkom śląskim). W Pradze miał możność obcowania z kontynuatorami słynnego Praskiego Kółka Lingwistycznego i zetknięcia się z metodologią semiotyczną. Tamże doktoryzował się pod opieką naukową prof. Karela Horálka (1968), następnie zdobył tytuł kandydata nauk (1973) i po raz drugi habilitował się w 1988 r. (pierwsza habilitacja - Uniwersytet Warszawski, 1978), a w 1994 roku uzyskał profesurę. Na czas zdobywania tytułów naukowych przypadają wspaniałe osiągnięcia edytorskie ${ }^{1} \mathrm{i}$ badawcze Profesora, na czele $\mathrm{z}$ Jego wybitną monografią ${ }^{2}$ z zakresu antropologii narracji, poświęconą osobie i twórczości narracyjnej Józefa Jeżowicza, stanowiącej nie tylko ważki dokument kultury osobniczej, ale również zbiorowej z terenu Zaolzia.

Kariera zawodowa prof. Kadłubca wiąże się z jego działalnością dydaktyczną, naukową i oświatową. Od 1964 r. pracuje jako polonista w Katedrze Języków Obcych Instytutu Pedagogicznego ostrawskiej Wyższej Szkoły Pedagogicznej (od 1991 - Uniwersytet), później zaś wykłada na Uniwersytecie Karola w Pradze. Od 1991 roku kieruje Zakładem Badań Etnikum Polskiego Uniwersytetu Ostrawskiego, wkrótce przekształconym w Instytut z siedzibą w Czeskim Cieszynie. Z inicjatywy profesora powstaje też jedyna na gruncie czeskim Katedra Polonistyki i Folklorystyki Uniwersytetu w Ostrawie, którą kieruje w latach 1990-1992. Jednostka ta, posiadając uprawnienia doktorskie i sporą kadrę, istnieje do dziś, choć od dawna przekształcono ją w jeden z trzech zakładów Katedry Slawistyki Wydziału Filozoficznego. W tejże instytucji w roku 2002 prof. Kadłubiec przeszedł na emeryturę, ale już w 2007 r. powrócił jako visiting professor, by dalej kontynuować swą działalność (aktualnie jako professor emeritus).

Równorzędnie prof. Karol D. Kadłubiec udziela się naukowo i organizacyjnie po drugiej stronie granicy. Wraz z prof.prof. Ireną Bukowską-Floreńską, Haliną Rusek i Alojzym Kopoczkiem organizuje w 1991 r. kierunek etnologiczny w cieszyńskiej filii Uniwersytetu Śląskiego w Katowicach. Tamże w latach 19952005 roku kieruje Zakładem Folklorystyki Ogólnej i Stosowanej, dzieląc się ze swymi licznymi studentami teoretyczną wiedzą folklorystyczną, którą zawsze łączył z praktyką etno-muzykologiczną. Tutaj pod jego opieką powstało wiele prac magisterskich, m.in. wypromował w 2007 r. dzieło znanego podhalańskiego regionalisty, dyrektora Domu Ludowego w Bukowinie Tatrzańskiej mgr. Bartka Koszarka (Zdobnictwo ludowe na Podhalu jako Znak. Na przykładzie Bukowiny Tatrzańskiej). Jego wiedza i talent muzyczny zostały docenione, gdy powołano Profesora do kierowania Radą Programową Zespołu Pieśni i Tańca „Śląsk”, noszącego dziś imię jego twórcy - Stanisława Hadyny (n.b. również pochodzącego z Karpętnej). W następnych latach, aż do emerytury Profesor kieruje Zakładem

$1 \quad$ K.D. Kadłubiec (red.), Płyniesz Olzo I. Zarys kultury duchowej ludu cieszyńskiego, Ostrava 1970; Idem (red.), Płyniesz Olzo II. Zarys kultury materialnej ludu cieszyńskiego, Ostrava 1972.

2 K.D. Kadłubiec, Gawędziarz cieszyński Józef Czechowicz, Ostrava 1973, ss. 442. 
Antropologii i Folklorystyki w Katedrze Pedagogiki, Psychologii i Antropologii Wydziału Humanistyczno-Społecznego Akademii Techniczno-Humanistycznej w Bielsku-Białej.

Jednakowoż na kompletną emeryturę Profesor nigdy nie odszedł, bo oto z jego inicjatywy w Ustroniu (pow. cieszyński) w 2013 r. otwarto letnią Wolną Szkołę Nauk Filozoficznych i Społecznych im. prof. Jana Szczepańskiego - ustronianina z urodzenia - w której pełni rolę honorowego rektora. Ideę owej szkoły zaczerpnął Kadłubiec z Dzienników Jana Szczepańskiego ${ }^{3}$, których był znakomitym edytorem, za co otrzymał Nagrodę Historyczną „Polityki” (2010).

Działalność społeczna Profesora wiąże się przede wszystkim z jego aktywnym członkostwem w Polskim Związku Kulturalno-Oświatowym (PZKO) na terenie Republiki Czeskiej. Do dziś kieruje Miejscowym Kołem (MK) w Mistrzowicach, gdzie od kilkudziesięciu lat mieszka z rodziną. Na terenie Zaolzia dał się poznać jako działacz Zarządu Głównego i incjator Sekcji Folklorystycznej (1965), która przez lat trzydzieści prężnie emanowała - po obu stronach granicy - na całe środowisko lokalnych muzealników, nauczycieli, młodzież i zespoły folklorystyczne oraz naukowców poprzez spotkania, prelekcje, akcje badawcze i wydawnicze.

Nic tedy dziwnego, że w świetle licznych, skrótowo wspomnianych wyżej dokonań Profesora, jubileusz jego 80. urodzin celebrowany był wyjątkowo uroczyście, przybierając formę benefisu, który zgromadził ponad dwieście osób. Organizatorem tej uroczystości, która odbyła się 9 września w Mostach koło Jabłonkowa w historycznym domu MK PZKO „Kasowy” był Kongres Polaków w Republice Czeskiej, na czele z jego prezesem inż. Mariuszem Wałachem, wspieranym przez inż. Andrzeja Niedobę, prezesa MK PZKO Mosty i jednocześnie znanego lokalnego literata.

Scenariusz uroczystości pt. „A” jak akademia, ułożonej w formie interaktywnego abecadła życia i dokonań Profesora, przeplatanego adresami gratulacyjnymi uczniów i przyjaciół, często utrzymanymi w tonie humorystycznym oraz radosnymi wystąpieniami artystycznymi opracowała dr Renata Putzlacher-Buchtová, a oprawę muzyczną zapewnił Polski Chór Mieszany „Collegium Canticorum” z Czeskiego Cieszyna, fragmenty zaś prac Profesora czytał aktor cieszyński Karol Suszka.

Ponadto specjalnie dla Profesora zagrali jego przyjaciele z Polski, Słowacji i Czech, jak to: kapela architekta i folklorysty Jana Karpiela-Bułecki z Zakopanego, istebniańska kapela „Wałasi” ze znakomitym skrzypkiem i gajdoszem Zbigniewem Wałachem oraz przejmującym śpiewem Kasi Brody, akompaniującej sobie na cymbałach cieszyńskich, wreszcie kapela pod gajdoszem Bernardem Garajem, profesorem etnomuzykologii i folklorystyki Uniwersytetu w Nitrze, a także młodzieżowy zespół ludowy „Bezmiana” z Bystrzycy i żeński chór „Sotóny” z Mostów.

3 Jan Szczepański, Dzienniki z lat 1935-1945, Przepisał, opracował i wstępem opatrzył Daniel Kadłubiec, Ustroń 2009, ss. 256; Jan Szczepański, Dzienniki z lat 1945-1968, przepisał, opracował i wstępem opatrzył Daniel Kadłubiec, Ustroń 2013, ss. 464. 
Wśród przemawiających naukowców obszerniejszy adres gratulacyjny złożyła doc. dr Jana Raclavská z Uniwersytetu Ostrawskiego, a pięknie wydaną księgę pamiątkową ${ }^{4} \mathrm{z}$ dwudziestoma artykułami ujętymi w cztery grupy tematyczne (I. Język-kultura-obraz świata; II. Przeszłość-mit-tożsamość; III. Dyskurs lokalny-folklor-literatura; IV. Symbolika-wspólnota-media) wręczyła Profesorowi dr Katarzyna Marcol z Uniwersytetu Śląskiego w Katowicach (patrz zdjęcie na stronie 250).

Na koniec podkreślmy, że uroczystość jubileuszowa przebiegała w nadzwyczajnej, pełnej humoru atmosferze, niezależnie od używanego na scenie języka, dialektu czy gwary, a pogoda ducha, humor i młodzieńczy temperament Profesora emanowały na wszystkich obecnych. Dodajmy też, że nasz Czcigodny Jubilat i niestrudzony badacz żywego słowa już ogłosił wydanie swej następnej książki. Ad multos annos Profesorze!

\section{Violetta Krawczyk-Wasilewska}

P.S. Właśnie ukazało się kolejne monumentalne dzieło (w j. polskim i czeskim) Profesora pt. Opowiado Anna Chybidziurowa, wyd. Ducatus Teschinensis, Bystřice 2017, ss. 544.

$\overline{4}$ K. Marcol i J. Kajfosz (red.), Językowe i kulturowe modelowanie świata. Księga dedykowana Profesorowi Karolowi Danielowi Kadłubcowi, Kongres Polaków w Rep. Czeskiej, Uniwersytet Śląski w Katowicach, Katedra Socjologii Wydz. Filozoficznego Uniwersytetu Ostrawskiego, Czeski Cieszyn 2017, ss. 323. 